\title{
Factors Influencing Teachers' Innovative Behaviour: A Systematic Review
}

\author{
Mohammed Afandi Zainal, Mohd Effendi Ewan Mohd Matore \\ Centre of Educational Planning and Policy, Faculty of Education, Universiti Kebangsaan Malaysia, Bangi, Selangor, Malaysia \\ Email: afan.zainal@gmail.com,effendi@ukm.edu.my
}

How to cite this paper: Zainal, M. A., \& Matore, M. E. E. M. (2019). Factors Influencing Teachers' Innovative Behaviour: A Systematic Review. Creative Education, 10, 2869-2886.

https://doi.org/10.4236/ce.2019.1012213

Received: October 21, 2019

Accepted: November 26, 2019

Published: November 29, 2019

Copyright (c) 2019 by author(s) and Scientific Research Publishing Inc. This work is licensed under the Creative Commons Attribution International License (CC BY 4.0).

http://creativecommons.org/licenses/by/4.0/

(c) (i) Open Access

\begin{abstract}
The rapid changes in 21st century of education system demand innovation actions from all teachers. The innovative behaviour is vital to ensure that education system remains relevant to current developments and trends. However, it has a lack of comprehensive identifications of its factors that can influence a teacher's innovative behaviour, especially in recent decades. This study employed a Systematic Literature Review (SLR) as a research method. The SLR consists of review protocol which specifies the topic to be researched and the method customized in conducting the review. It is the main strategy of detecting relevant literature review and how information is obtained from the primary study. Planning, conducting, and reporting the review are phases of the SLR method. The study found that leadership and self-efficacy are the most dominant factors in influencing teachers' innovative behaviour in the school sector. Detailed empirical studies need to be done to see whether leadership and self-efficacy factors influence the teachers' innovative behaviour directly or indirectly as potential mediator and moderators. The research can be improved by filtering articles in foreign languages, using a more extensive database and exploring other factors through in-depth interviews. It is recommended that the identified factors be used in different settings and also focusing on non-dominant factors.
\end{abstract}

\section{Keywords}

Innovative Behaviour, Influence, Systematic Literature Review, School, Teachers

\section{Introduction}

Innovation is probably one of the hottest themes that may never fade from being discussed academically around the world. The rationale behind this is the belief of its great importance not only to the organization, but to the community, the 
nation, and the entire human race. Innovation often defined as change, invention, and the creation of opportunities that are essential to the survival, success, growth, and excellence of a better civilization. In today's increasingly challenging eras, innovation is seen as a key to maintain a competitive edge not only for the individual but for the organization as well. Today's aggressive competition requires the ability and capability to constantly innovate to ensure that we have the advantage and are at the forefront of success. Innovation nowadays not only guarantees success and recognition, but it has also become a vital aspect of staying relevant and staying alive.

Although innovation is known as crucial to humans, the reality is that innovation is often associated with specific areas only such as business, engineering, and technology (Asurakkody \& Shin, 2018). In these areas, innovation is often mentioned as a key element in ensuring organizational sustainability and success (Leong \& Rasli, 2014). Of course, other critical areas such as education cannot be overlooked in accepting this phenomenon of innovation. The current situation in the rapidly expanding educational system is also demanding innovation actions among all teachers. Being in the 21st century today requires a relevant education system in line with current needs. Innovation is needed to help education in keeping pace with the advent of the rapidly growing industrial revolution 4.0 era. In education, innovation is one of the critical factors that need attention and cannot be ignored (Kundu \& Roy 2016). Some actions of innovation can make critical changes in improving the education system. In the context of teaching, for example, innovation can improve the environment that can help students to success in learning. A little touch of innovation from the teachers will lead to more creative learning methods, more comprehensive implementation of teaching methods and the use of new tools and technologies that will surely benefit the students and education system overall.

In order to meet the needs of an organization's innovation, one of the key elements to note is the innovative behaviour of the individuals involved. Since organizational change depends on behaviour, individual innovative behaviour is fundamental to the success and survival of the organization. Innovative behaviour according to (Baskaran \& Rajarathinam, 2018) is a process by which new ideas are generated, created, developed, implemented, encouraged, realized, and modified by individuals to enhance organizational effectiveness and performance. In other words, innovative behaviour is the construction of a broad range of individual behaviours that includes not only the generating of ideas but also transforming ideas into concrete innovations for organizational goodness (Devloo et al., 2015). In education, teachers are recognized as a significant pillar in any educational organization. Teachers play a vital role in ensuring the success and effectiveness of the education system. Therefore, the innovative behaviour of teachers should be given much attention to ensure that the education system remains relevant to current developments.

Catio (2019) argues that there are three main reasons why innovative behaviour among teachers should be emphasized. According to Catio (2019), innovative 
behaviour will help teachers stay up to date with the ever-changing society. The demands and requirement of today's educated society are very different compared to the past. Today's society not only demands students who are good at reading and counting at school but also demands students who are capable of thinking creatively, critically and capable of solving problems. With creativity and innovative behaviour, teachers are not only will achieve the complex educational goals but also will be able to inculcate critical skills of the students which can help students to act more effectively in today's globalized world (Afida, Aini, \& Rosadah, 2013). Second, the rapid development of technologies that can facilitate the teaching and learning process at this age certainly requires teachers' innovative behaviour. As technology advances, the old ways of teaching become less relevant to the current needs of education because technologies use in teaching and learning nowadays had become very diverse and a central to teaching process (Melor, 2018). Therefore, teachers need to be continuously changed to ensure that the methods used remain relevant and this will require the innovative behaviour of teachers. The third is an example of student follow-up. In creative behaviour, Adzliana Mohd et al. (2012) stated that teachers can play a role in model behaviour by showing and sharing their personal behaviour with students. Therefore, it is also possible that teachers who have innovative behaviour will also set a good example and be a role model that can be a starting point for producing innovative citizens in the future. In short, teachers' innovative behaviour is crucial to the development of the education system, and school organizations which can help to create enlightened society. Thus, innovative behaviour should be seen as a critical element in the education profession.

In order to enhance the innovative behaviour of teachers, it is important to know the factors that can influence the teachers' innovative behaviour either directly or indirectly. Therefore, this study will attempt to identify and analyze the factors that may influence teachers' innovative behaviour in their work based on previous researcher studies. It is also wished that this study will contribute to the conceptualization of future research on teachers' innovative behaviour.

\section{Methodology}

The Systematic Literature Review (SLR) used in this study is a systematic and explicit method for the purpose of identifying, selecting, critically evaluating, collecting and analysing data from relevant past research (Moher et al., 2009). This method was chosen because it helps to synthesize all relevant academic literature in depth. The systematic literature review that has been conducted is based on the method proposed by Petticrew \& Roberts (2006). In this study, all articles related to teachers "innovative behaviours were systematically viewed to achieve the main goal of the study which was to identify the factors that may influence teachers" innovative behaviours. The results of this systematic literature review will provide an overview of the factors involved in developing an initial conceptual framework of studies on teacher innovative behaviour. 


\subsection{Searching Strategy}

The process of finding relevant articles has focused on three major databases in the academic world namely, SCOPUS, ERIC and Google Scholar. Figure 1 shows the article selection process adapted from Karabulut-Ilgu, Jaramillo Cherrez \& Jahren (2018). The keywords "tingkah laku kerja inovatif guru" and "tingkah laku inovatif guru" in Malay language and "teacher innovative work behaviour/behavior" and "teacher innovative behaviour/behavior" for English have been searched. The searching process by using these keywords has also been done by limiting the publication year from January 2010 to July 2019 in order to get the recent articles.

\subsection{Selection Criteria}

In order to get the right and suitable articles, a few stages of filtering over the original articles were obtained (Figure 1). The first screening is conducted based on several criteria for acceptance and rejection. The three criteria for rejection were 1) articles that were not fully accessible, 2) articles or studies that were not in the context of the teacher, and 3) articles or studies that were in the language other than Malay and English. Acceptance criteria were 1) complete usage of the keywords, 2) full access to articles 3) research in the context of teachers and 4) articles in Malay or English.

The second step is to remove articles and previous studies that are repeated through the reading of titles and abstracts each. The final analysis is done by a full and depth reading of the remaining articles in order to take out the articles that are not relevant to the research needs. As a result of the search and filtering process, 42 articles were selected (Table 1).

\section{Results and Discussion}

The main objective of this study is to identify factors that can influence innovative behaviour among teachers through a systematic literature review. In general, the total 46 factors have been identified to have a significant effect on the innovative

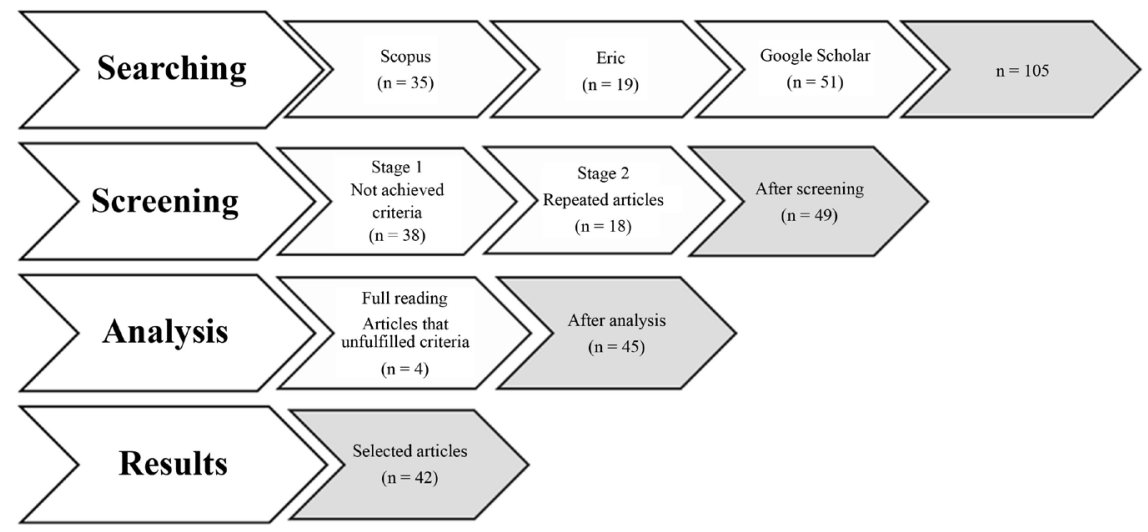

Figure 1. Article selection process adapted from Karabulut-Ilgu, Jaramillo Cherrez, \& Jahren (2018). 
behaviour of the teacher either directly or indirectly. Thurlings, Evers and Vermeulen (2015) and Zennouche, Zhang and Wang (2014) in their study suggested that factors influencing innovative behaviour can be categorized into several groups according to characteristics and similarities between factors. This study used the categories proposed by Thurlings et al. (2015) since the study is more relevant to the context of teachers and education, which is named as demographic, individual and organizational factors. Individual factors were the most

Table 1. Overview of the included studies.

\begin{tabular}{|c|c|c|}
\hline Author \& Year & Country & Studies \\
\hline Chou et al. (2019) & Taiwan & $\begin{array}{l}\text { Analyse the correlation among teachers' perceived acceptance of technological innovation, } \\
\text { organisations' innovation climate, and innovative teaching using information and } \\
\text { communication technology (ICT). }\end{array}$ \\
\hline Huang, Lee, \& Dong (2019) & China & $\begin{array}{l}\text { Explore teachers' perceptions of their creativity and receptivity to creative teaching from the } \\
\text { perspective of educational change. }\end{array}$ \\
\hline Aslan \& Kesik (2018) & Turkey & Exploring the individual innovativeness levels of high school teachers. \\
\hline Baskaran \& Rajarathinam (2018) & India & $\begin{array}{l}\text { Measure the level of innovative behaviour and examine the relationship between } \\
\text { demographic variables and innovative behaviour among the faculty of teaching in } \\
\text { educational institutions. }\end{array}$ \\
\hline Bednall et al. (2018) & $\begin{array}{l}\text { USA } \\
\text { Netherlands }\end{array}$ & $\begin{array}{l}\text { Examine the relationship between leadership and innovative behaviour within and between } \\
\text { teams. }\end{array}$ \\
\hline Izzati (2018) & Indonesia & $\begin{array}{l}\text { Determine the relationship between organizational climate and innovative behaviour of } \\
\text { vocational school teachers. }\end{array}$ \\
\hline $\begin{array}{l}\text { Lecat, Beausaert, \& Raemdonck } \\
\qquad(2018)\end{array}$ & Belgium & $\begin{array}{l}\text { Studying relations between (in)formal learning activities, employability and innovative } \\
\text { behaviour. }\end{array}$ \\
\hline $\begin{array}{l}\text { Klaeijsen, A., Vermeulen, M., \& } \\
\text { Martens (2018) }\end{array}$ & Netherlands & $\begin{array}{l}\text { Exploring more insight into motivational processes contributing to teachers' innovative } \\
\text { behaviour. }\end{array}$ \\
\hline Shahab \& Imran (2018) & Pakistan & $\begin{array}{l}\text { Identifying the role of ethical work context along with internal social capital in creation of } \\
\text { innovative behaviour among teachers. }\end{array}$ \\
\hline Çoklar \& Özbek (2017) & Turkey & $\begin{array}{l}\text { Determine the effect of teachers' individual innovativeness level on the technological } \\
\text { integration process. }\end{array}$ \\
\hline Messmann et al. (2017) & German & $\begin{array}{l}\text { Examine the effect of job demands, psychological empowerment, and participative safety on } \\
\text { vocational teachers' innovative behaviours. }\end{array}$ \\
\hline Suharyati (2017) & Indonesia & $\begin{array}{l}\text { Examine the correlation between dependent variables teacher's job motivation with an } \\
\text { independent variable, innovativeness. }\end{array}$ \\
\hline Aziah, Norkursiah, \& Ghani (2016) & Malaysia & $\begin{array}{l}\text { Determine the level of psychological empowerment and innovative behaviour among } \\
\text { secondary teachers. }\end{array}$ \\
\hline Doç \& Yapıcı (2016) & Turkey & Examine the individual innovativeness levels of pre-service biology teachers. \\
\hline Gkorezis (2016) & Greece & $\begin{array}{l}\text { Examine the relationship between principal empowering leadership and teachers' } \\
\text { innovative behaviour. }\end{array}$ \\
\hline $\begin{array}{l}\text { Iqra Abdullah, Rozeyta Omar, \& } \\
\quad \text { Siti Aisyha Panatik (2016) }\end{array}$ & Not specified & $\begin{array}{l}\text { Exploring the relationship of personality with creativity and innovative behaviour explored } \\
\text { in depth. }\end{array}$ \\
\hline
\end{tabular}




\section{Continued}

\begin{tabular}{|c|c|c|}
\hline Kundu \& Roy (2016) & India & Role of perceived school climate for innovative behaviour of teachers. \\
\hline Noh, Hamzah, \& Abdullah (2016) & Malaysia & $\begin{array}{l}\text { Explore the impact of experience in using a computer and the level of ICT knowledge } \\
\text { towards personal innovativeness. }\end{array}$ \\
\hline Runhaar et al. (2016) & Netherlands & The effects of task interdependence on VET teachers' innovative behaviour. \\
\hline $\begin{array}{l}\text { Yorulmaz, Çokçalişkan, \& Önal } \\
\qquad(2016)\end{array}$ & Turkey & $\begin{array}{l}\text { Determine the pre-service classroom teachers' state of innovativeness and investigate it in } \\
\text { relation to different variables. }\end{array}$ \\
\hline Balkar (2015) & Turkey & $\begin{array}{l}\text { Investigate the relationships between the organizational climate characterized by support, } \\
\text { cohesion, fairness and pressure, job performance and innovative behaviour of teachers. }\end{array}$ \\
\hline Ramli, Abdul, \& Halim (2015) & Malaysia & Investigate the influence of leadership styles on teachers' innovative behaviour. \\
\hline Sağnak et al. (2015) & Turkey & $\begin{array}{l}\text { Examine the mediating effect of psychological empowerment on the relationship between } \\
\text { leadership and innovative climate. }\end{array}$ \\
\hline Yilmaz \& Bayraktar (2014) & Turkey & $\begin{array}{l}\text { Investigating teacher's attitudes towards educational technologies with regards to their } \\
\text { innovativeness levels. }\end{array}$ \\
\hline Bourgonjon et al. (2013) & Belgium & $\begin{array}{l}\text { Study on the factors that influence the acceptance of commercial video games as learning } \\
\text { tools in the classroom. }\end{array}$ \\
\hline Celik (2013) & Turkey & $\begin{array}{l}\text { Determine the effect of individual innovativeness, family socioeconomic levels and gender } \\
\text { on teachers' sense of efficacy. }\end{array}$ \\
\hline Nemeržitski et al. (2013) & Estonia & $\begin{array}{l}\text { Explores the possible school environmental factors that may support the innovative } \\
\text { behaviour of teachers. }\end{array}$ \\
\hline Al-husseini \& Elbeltagi (2012) & Iraq & Effect of leadership on innovation in education institutions. \\
\hline Binnewies \& Gromer (2012) & Not Specified & $\begin{array}{l}\text { Examine the role of work characteristics and personal initiative for teachers' idea } \\
\text { generation, idea promotion, and idea implementation. }\end{array}$ \\
\hline $\begin{array}{l}\text { Javed Iqbal, Waheed, \& Naveed } \\
\text { Riaz (2012) }\end{array}$ & India & $\begin{array}{l}\text { Examine the relationship between leadership style and innovative behaviour in educational } \\
\text { institutions }\end{array}$ \\
\hline $\begin{array}{l}\text { Loogma, Kruusvall, \& Ümarik } \\
\qquad(2012)\end{array}$ & Estonia & $\begin{array}{l}\text { Analyse the acceptance of e-learning by teachers of vocational secondary and professional } \\
\text { higher education institutions. }\end{array}$ \\
\hline Sellars (2012) & Australia & $\begin{array}{l}\text { Indicated that professional attitude and norms were necessary for teacher professional } \\
\text { change. }\end{array}$ \\
\hline $\begin{array}{l}\text { Chang, Chuang, \& Bennington } \\
\text { (2011) }\end{array}$ & Taiwan & $\begin{array}{l}\text { Investigate the relationship between creative teaching behaviours and innovation-fostering } \\
\text { elements of the organizational climate in schools. }\end{array}$ \\
\hline $\begin{array}{l}\text { Donnelly, McGarr, \& O’Reilly } \\
\qquad \text { (2011) }\end{array}$ & Ireland & $\begin{array}{l}\text { Describes attempts to integrate an ICT-based resource (a Virtual Chemistry Laboratory) } \\
\text { into some science teachers' practice. }\end{array}$ \\
\hline Hsiao et al. (2011) & Taiwan & Examine the impact of self-efficacy on innovative behaviour for teachers \\
\hline Messmann \& Mulder (2011) & German & $\begin{array}{l}\text { Investigate how and why innovations at work are developed and enacted among vocational } \\
\text { teachers. }\end{array}$ \\
\hline Nakata (2011) & Japan & $\begin{array}{l}\text { Investigate teachers' readiness for promoting learner autonomy by exploring the perceived } \\
\text { importance of and the use of strategies. }\end{array}$ \\
\hline Opfer, Pedder, \& Lavicza (2011) & England & $\begin{array}{l}\text { Test a hypothesised model of teacher orientation to learning (consisting of beliefs, practice } \\
\text { and experiences about learning) and its relationship to teacher learning change. }\end{array}$ \\
\hline Borasi \& Finnigan (2010) & USA & $\begin{array}{l}\text { Explores how the preparation of educators committed to improving education can } \\
\text { capitalize on entrepreneurship and identify specific attitudes and behaviours considered } \\
\text { typical of entrepreneurs that contributed to educators' success. }\end{array}$ \\
\hline McDougall (2010) & Australia & $\begin{array}{l}\text { Analyses the discourses that emerged from interviews with primary teachers who talked } \\
\text { about their reactions to teaching media. }\end{array}$ \\
\hline Pieterse et al. (2010) & Netherlands & Exploring the relationship between leadership and innovative behaviour. \\
\hline
\end{tabular}


frequently studied factors with a total of 22 factors, followed by organizational with a total of 18 factors. Demographic factors recorded the lowest with only 6 factors in total.

\subsection{Demographic Factor}

Table 2 shows all the factors that fall into the demographic category. In total, six factors from ten studies were identified namely gender (4 studies) teacher's age (3 studies), school demographics (3 studies), teaching experience (3 studies) teacher eligibility (3 studies) and student level (2 studies). Although gender recorded the highest frequency of study, three of these studies were conducted in the same location in Turkey (Aslan \& Kesik, 2018; Doç \& Yapıc1, 2016; Yorulmaz et al., 2016). All six factors in this demographic category were studied in relation to teachers' innovative behaviour directly without using other factors as mediators and moderators. Two factors have different definitions: school demographic factors and teacher education level. For school demographic factors, three different definitions have been identified namely school location (Aziah et al., 2016; Chang et al., 2011), school type (Aslan \& Kesik, 2018) and school size (Chang et al., 2011). In terms of teacher education factors, two different definitions have been proposed namely teacher education level (Baskaran \& Rajarathinam, 2018; Noh et al., 2016) and academic achievement of teachers (Yorulmaz et al., 2016).

\subsection{Individual Factor}

Table 3 provides a summary of the results from previous studies on individual factors in influencing teachers' innovative behaviour. A total of 22 factors from the previous 22 studies were successfully identified. These factors are then broken down into three groups by main categories namely personality, attitude and

Table 2. Previous research of teacher's innovative behaviour related to demographic factors.

\begin{tabular}{|c|c|c|c|c|c|c|c|c|c|c|c|}
\hline Authors & 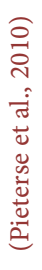 & 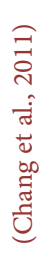 & 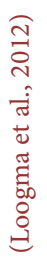 & 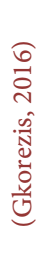 & 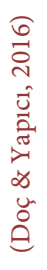 & 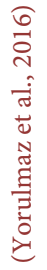 & 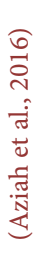 & 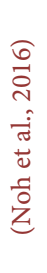 & 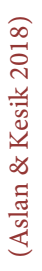 & 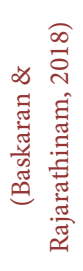 & Total \\
\hline Gender & & & & & * & * & & & * & * & 4 \\
\hline Age & * & & & & & & & & * & * & 3 \\
\hline School demographic & & * & & & & & * & & * & & 3 \\
\hline Teaching experiences & & & * & * & & & & & & * & 3 \\
\hline Students level been taught & & & & & * & * & & & & & 2 \\
\hline Teacher qualifications & & & & & & * & & * & & * & 3 \\
\hline
\end{tabular}


Table 3. Previous research of teacher's innovative behaviour related to individual factors (2010-2019).

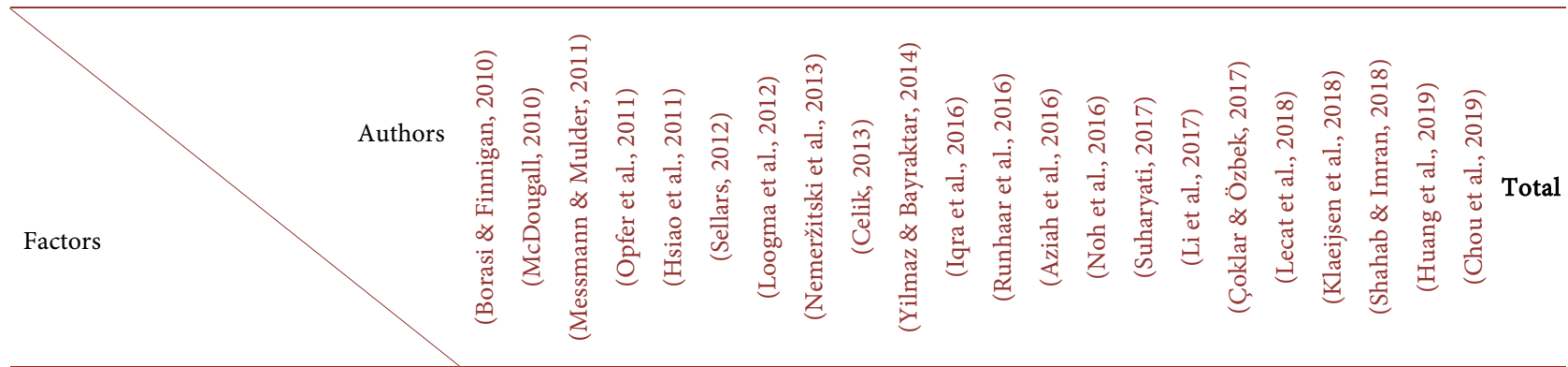

\section{PERSONALITY}

Curiosity

Openness

Risk-taker

Learning styles

Social capital

Persistence

ATTITUDES

Vision

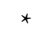

Commitment

Professionalism

Happiness

Teaching \& learning strategy

Attitude toward opportunity

Motivation

Psychological empowerment

Job satisfaction

Self-efficacy

Attitude toward teaching \& learning

Proactive

Acceptance of innovation and ICT

SKILL

Decision-making

Problem-solving

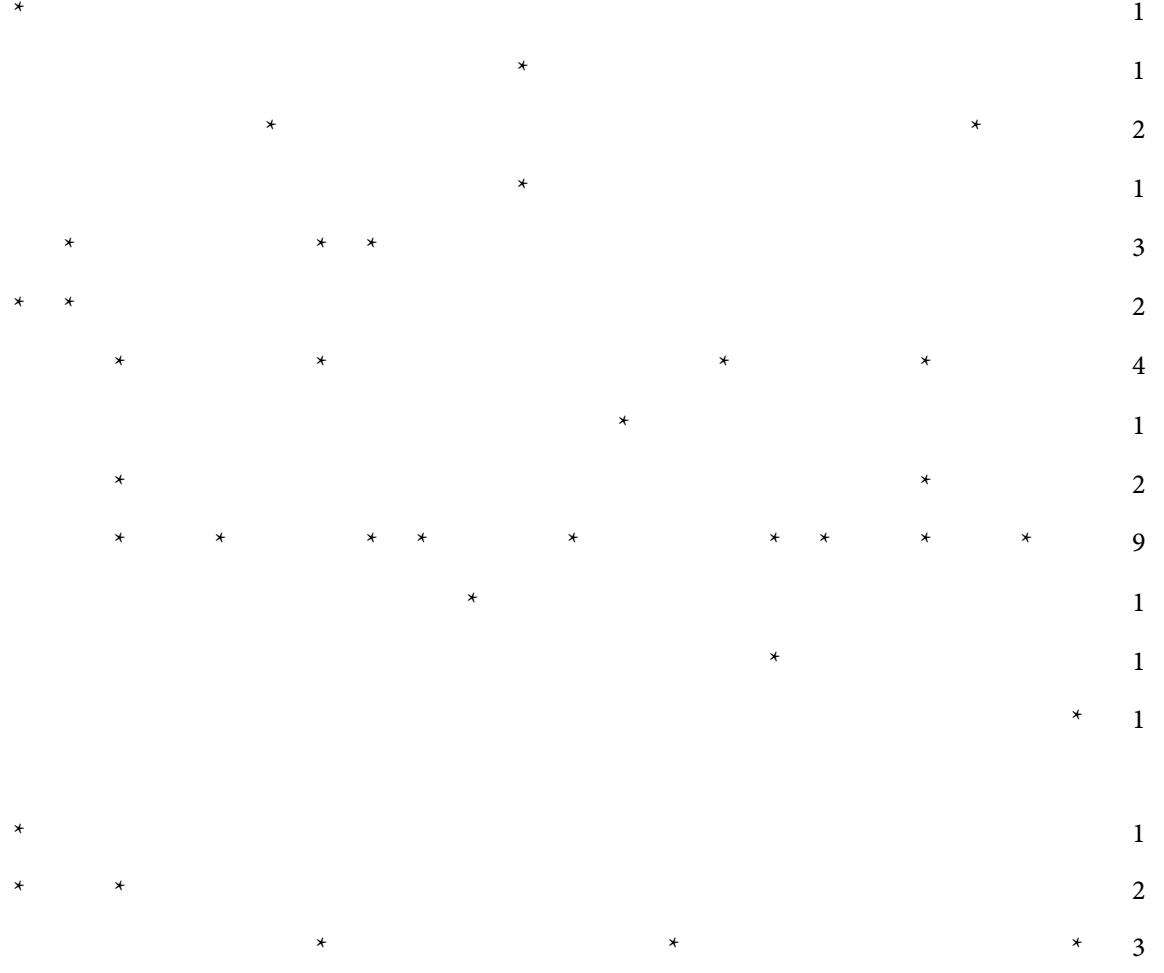

skills. These individual factors can also be summarized as internal factors to influence teachers' innovative behaviour. The personality categories in this study were defined as the personality or character of a teacher that influenced their innovative behaviour. Past reviewers have explored six personality category factors: curiosity ( 1 study), openness (1 study), risk-taking (1 study), persistence (1 study), social capital (1 study) and learning methods or learning styles (2 studies). 
All six studies on these personality factors are the result of studies using the same background that is from the European continent.

Attitudes categories can also be defined as teachers' attitudes or views that influence innovative behaviour. There are 13 factors in this category: vision (1 study), commitment (1 study), professionalism (2 studies), excitement or happiness ( 1 study), tendency of teaching and learning strategy used in teaching ( 3 studies), attitude toward opportunity (2 studies), motivation (4 studies), psychological empowerment (1 study), job satisfaction ( 2 studies), self-efficacy ( 9 studies), attitude toward teaching and learning (1 study), proactive (1 study) and acceptance of innovation and ICT (1 study). In contrast to personality categories, attitude categories are widely studied as a result of 18 different researchers with backgrounds from around the world.

Skills category is a category that engages teachers' competencies and abilities in matters that influence innovative behaviour. This category is the least important of the three factors that previous researchers have studied. The three factors are decision-making skills ( 1 study), problem-solving skills (2 studies) and ICT skills (3 studies). All six studies on this factor are the result of studies using the same background from the European continent.

\subsection{Organizational Factor}

Table 4 shows the total of 18 organizational factors identified in this study.

Table 4. Previous research of teacher's innovative behaviour related to organizational factors (2010-2019).

\begin{tabular}{|c|c|c|c|c|c|c|c|c|c|c|c|c|c|c|c|c|c|c|c|c|c|c|c|}
\hline Authors & 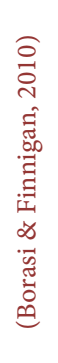 & 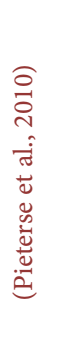 & 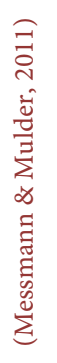 & 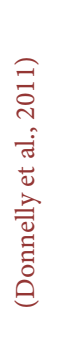 & 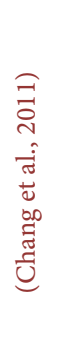 & 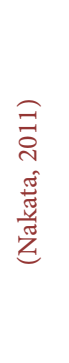 & 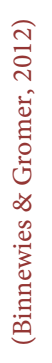 & 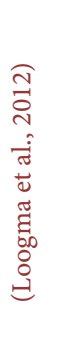 & 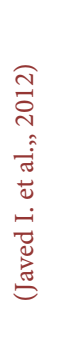 & 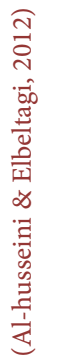 & 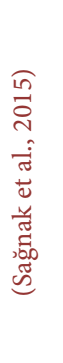 & 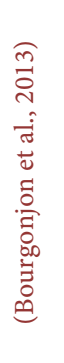 & 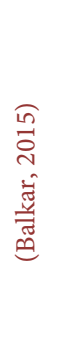 & 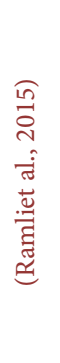 & 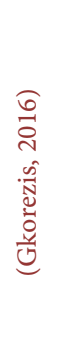 & 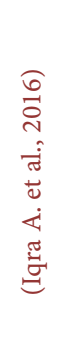 & 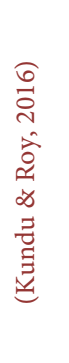 & 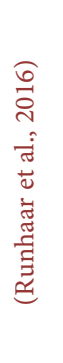 & 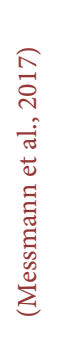 & 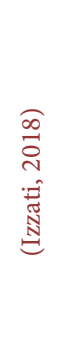 & 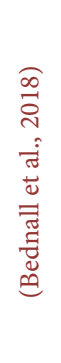 & 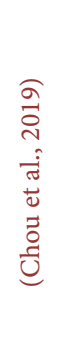 & Total \\
\hline Organization vision & * & & & & & & & & & & & & & & & & & & & & & & 1 \\
\hline Policy & & & * & & * & & & & & & & & & & & & & & & & & & 2 \\
\hline Organization network & * & & & & & & & & & & & & & & & & & & & & & & 1 \\
\hline Leadership & & * & & & * & & * & * & * & * & & & & * & * & & & & & & * & & 9 \\
\hline Co-worker relationships & & & & & * & & * & & & & & & & & & & & & & & & & 2 \\
\hline Communication & & & * & & & & & & & & & & & & & & & & & & & & 1 \\
\hline Resources & & & * & & * & & & & & & & & & & & & & & * & & & & 3 \\
\hline Transparency & & & * & & & & & & & & & & & & & & & & & & & & 1 \\
\hline Classroom layout & & & * & & & & & & & & & & & & & & & & & & & & 1 \\
\hline Students achievement & & & * & & & & & & & & & & & & & & & & & & & & 1 \\
\hline Professional development & & & & * & & & & & & & & & & & & & & & & & & & 1 \\
\hline
\end{tabular}




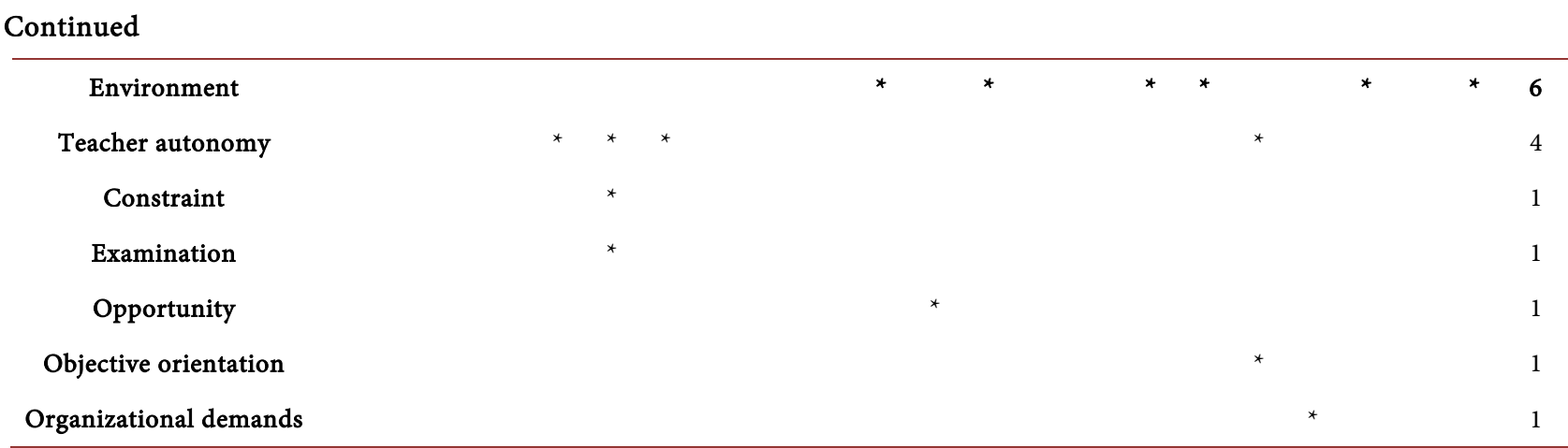

These 18 factors are the result of 23 previous studies. Organizational factors in this study refer to external factors that exist within the organization but are beyond the control of teachers and can affect their innovative behaviour. Based on the analysis conducted, two factors namely leadership (9 studies) and environment (6 studies) recorded the highest frequency far outweighing other factors. As for the leadership factor, there are two different approaches to the previous researcher on studying this factor. 6 out of 9 studies have examined the impact of school administration leadership approaches on teacher innovative behavior (Al-husseini \& Elbeltagi, 2012; Banks et al., 2016; Bednall et al., 2018; Gkorezis, 2016; Javed Iqbal et al., 2012; Pieterse et al., 2010; Ramli et al., 2015). Meanwhile, the remaining three studies have examined the behaviour and support of leaders for teachers' innovative behaviour. For teacher autonomy and resources, there were four and three studies each, respectively. The policy factors and co-worker relationships recorded a frequency of 2 studies each. The other twelve factors covered only one study, namely vision, networking, communication, transparency, classroom layout, student achievement, professional development, constraints, exams, opportunities, objectives and organizational demands. All these factors are the result of a study based on multiculturalism from around the world.

\subsection{Discussion}

Based on the systematic literature review, this study found that there are a variety of factors that can influence teachers' innovative behaviour either directly or indirectly. These factors have been categorized into three groups, namely demographics, individuals and organizations according to the characteristics and similarities of the initially identified factors. Based on the findings, one of the most interesting issues to discuss is the existence of factors that are of increasing popularity and dominance over other factors. It is fascinating to learn more about why these factors are popular and dominant in studies that involve innovative behaviour among teachers. The two factors that have the highest frequency and are dominant over the other are the leadership and self-efficacy factors. Both factors accounted for $45 \%$ of all previously identified studies. Therefore, this section of the discussion will try to make a small contribution to the litera- 
ture by focusing on this matter.

Leadership factors are the most popular and frequently studied factors. One of the reasons why leadership factor is so dominant in the study of teacher innovative behaviour is that the topic of leadership is one of the most widely studied issues in the social sciences (Moghimi \& Muenjohn, 2014). A comprehensive study conducted by Dinh et al. in 2014 has identified 752 articles related to leadership topics, but to date, researchers have not been able to develop a single universal general leadership model. This shows that leadership is a very subjective matter, and it depends entirely on the factors of the current situation and context (Moghimi \& Muenjohn, 2014). This also indicates that the topic of leadership is pervasive, and thus, it becomes one of the most used factors in the context of teachers' innovative behaviour. Various sub-topics in the field of leadership, such as leadership style, for example, have also attracted researchers to study more intensely. Besides, leadership is generally recognized as one of the key factors that determine the success of an organization (Ahmad, 2012; Al-sharafi \& Rajiani, 2013; Arham, Boucher, \& Muenjohn, 2013). More specifically, some researchers also state that leadership is also one of the key factors and drivers of organizational innovation (Asiah et al., 2016; Choi et al., 2016; Javed et al., 2012; Masood \& Afsar, 2017). These researchers assume that great leadership responsibilities especially in prioritizing, making decisions, and having the power and commitment to improving organizational performance have made it a driving force behind individual innovation. Such a view that elevates the leadership factor as a critical component of an organization has made it so important in every aspect. Also, the relationship between leadership and innovation may be the reason why leadership factors are so dominant in this study. In management, for example, leadership and innovation are a trendy and recurring theme (Vogel \& Masal, 2015; De Vries, Bekkers, \& Tummers, 2016). It is the same with recent studies from other areas such as business and health. Both areas also acknowledge that leadership and innovative behaviour, in particular, have a significant relationship (Choi et al., 2016; Mokhber, Khairuzzaman, \& Vakilbashi, 2018; Wang et al., 2019). This for surely has indirectly brought the attention of innovative behaviour researchers in the context of teachers and education to also examined whether leadership is an important aspect or not.

Self-efficacy factors are the individual factors that have the highest frequency in teacher innovative behaviour studies. Bandura (1986), a precursor to self-efficacy, explains that self-efficacy is an individual's judgment of his or her ability to manage and perform all kinds of actions to achieve a set outcome. Self-efficacy is also not a matter of one's skill, but it is a consideration of their ability to do something using their skills. In short, self-efficacy is the result of the process of considering, integrating, and evaluating information about an individual's ability to make decisions or choices in each endeavour. According to Bandura, self-efficacy would also have an impact on individual performance. Baharin et al. (2016) and Tims, Bakker, and Derks (2014) state that self-efficacy 
can enhance one's ability and individuality which in turn improves performance and professionalism. However, different findings have been proposed by Schunk and DiBenedetto (2016) where their findings suggest that high self-efficacy can also have a negative impact on individuals. For example, individuals with high self-efficacy are likely to become overconfident and take things easy without trying too hard. These differences of opinion have made this factor a worthwhile one to study because it can provide two different effects simultaneously. Besides, self-efficacy is also believed to be able to have an impact or influence on an individual's behaviour, especially on effort and resilience to overcome obstacles (Thurlings et al., 2015) and willingness in accepting changes (Shamsudin \& Rosadah, 2018). Therefore, it is not possible if thoughts about the potential of self-efficacy in influencing innovative behaviour emerge as it has been recognized to affect individual behaviour especially which is known as a part in innovation process. Furthermore, the study of self-efficacy in education is not new and had been well established. Studies on teacher self-efficacy have long been initiated but are more focused on direct effects such as teaching effectiveness (Ng, Nicholas, \& Williams, 2010), student achievement (Norita, 2012) and overall teacher performance (Khan, Fleva, \& Qazi, 2015). This show that teacher self-efficacy is generally an important dimension that needs attention in education. Given the importance of teacher self-efficacy based on previous studies, it is fully understood why the many researcher selects this topic for teachers' innovative behaviour. The combination of factors that recognize their importance (self-efficacy) and new fields (teachers' innovative behaviour) will undoubtedly contribute useful and valuable knowledge for the benefit of the education system.

\section{Conclusion}

This study aims to systematically identify factors that influence innovative behaviour among teachers specifically for the current 10 -year study period. A total of 46 factors from three groups namely demographics, individuals and organizations were identified. It can be concluded that innovative behaviour among teachers is not influenced by just one factor. Like other human behaviours, many factors and variables can influence innovative behaviour. In summary, this study has touched on two factors that have the highest frequency of studies in teachers' innovative behaviour. The importance and relevance of leadership and self-efficacy factors of teachers' innovative behaviour have been briefly described to provide some insight and contribution to the knowledge in future teacher behaviour research.

It is undeniable that the leadership factor is so dominant in this study, but the fact is that it is still lacking and deserves more attention. The total of 10 studies in the last ten years from around the world is not a huge number compared to the population involved. This clearly indicates that research on innovative behaviour among teachers is still scarce. More in-depth research is needed as 
many factors have yet to be explored especially in the context of teachers and education compared to other fields.

It is hoped that this study will provide some idea for researchers to further develop this knowledge, especially in the Malaysian context. Besides, this study is also expected to provide some insight into the factors of innovative behaviour among teachers over the last ten years and to provide some insights to stakeholders in efforts to improve innovation behaviour among educators especially teachers. In today's fast-paced world of education and educational reform, innovative behaviour is a crucial area for teachers to improve in order for education to remain relevant in achieving their goals.

For future studies, it is recommended that more detailed studies be conducted to understand the influence of the factors identified in this study. It is necessary to study in depth whether these factors act directly or as mediators and moderators of innovative behaviour among teachers so that appropriate action can be taken while contributing to the field of knowledge. Futures researcher also suggested exploring more valuable factors through in-depth interviews of the related experts, filtering articles in other foreign languages and using a wider database.

\section{Acknowledgements}

This research was supported by the Universiti Kebangsaan Malaysia under the Dana Penyelidikan FPend (GG-2019-034) and UKM PP-FPEND-2019.

\section{Conflicts of Interest}

The authors declare no conflicts of interest regarding the publication of this paper.

\section{References}

Adzliana Mohd, D., Punia, T., Jizah, O., \& Kamisah, O. (2012). Creativity in Science Education. Procedia-Social and Behavioral Sciences, 59, 467-474. https://doi.org/10.1016/j.sbspro.2012.09.302

Afida, A., Aini, H., \& Rosadah, A. M. (2013). A Review of Research on Creative Teachers in Higher Education. International Education Studies, 6, 8-14. https://doi.org/10.5539/ies.v6n6p8

Ahmad, Z. A. (2012). Leading Innovation: A Matter of Style. In ICIMTR 2012-2012 International Conference on Innovation, Management and Technology Research (p. 716). https://doi.org/10.1109/ICIMTR.2012.6236488

Al-husseini, S., \& Elbeltagi, I. (2012). The Impact of Leadership Style and Knowledge Sharing on Innovation in Iraqi Higher Education Institutions. In Proceedings of the 4th European Conference on on Intellectual Capital (pp. 26-35).

Al-sharafi, H., \& Rajiani, I. (2013). Leadership Practices and Talent Turnover: Study on Yemeni Organizations. Business and Management Research, 2, 60. https://doi.org/10.5430/bmr.v2n3p60

Arham, A. F., Boucher, C., \& Muenjohn, N. (2013). Leadership and Entrepreneurial Suc- 
cess : A Study of SMEs in Malaysia. World Journal of Social Sciences, 3, 117-130.

Asiah Omar, N., Nazri, M., Alam, S. S., \& Ahmad, A. (2016). Assessing the Factors Influencing Service Innovation Capabilities and Performance. Information Management and Business Review, 8, 52-63.

Aslan, H., \& Kesik, F. (2018). An Investigation of Individual Innovativeness Characteristics of High School Teachers According to Certain Variables. Journal of Human Sciences, 15, 2215-2228. https://doi.org/10.14687/jhs.v15i4.5409

Asurakkody, T. A., \& Shin, S. Y. (2018). Innovative Behavior in Nursing Context: A Concept Analysis. Asian Nursing Research, 12, 237-244.

https://doi.org/10.1016/j.anr.2018.11.003

Aziah, I., Norkursiah, Z. A. W., \& Ghani, A. A. (2016). Do Malaysian Teachers' Innovative Behavior Influenced by Psycological Empowerment. In International Conference on Business and Social Sciences (pp. 286-299).

Baharin, B., Adnan, H., Zin, M. H., Kamaludin, N., \& Mansor, A. N. (2016). Gaya Kepimpinan Guru Besar Dan Tahap Efikasi Guru. Journal of Personalized Learning, 2, 9-17.

Balkar, B. (2015). The Relationships between Organizational Climate, Innovative Behavior and Job Performance of Teachers. International Online Journal of Educational Sciences, 7, 81-92. https://doi.org/10.15345/iojes.2015.02.007

Baskaran, K., \& Rajarathinam, M. (2018). Innovative Teaching Practices in Educational Institutions (ITPEI). International Journal of Educational Sciences, 20, 72-76.

Bednall, T. C., E. Rafferty, A., Shipton, H., Sanders, K., \& Jackson, C. J. (2018). Innovative Behaviour: How Much Transformational Leadership Do You Need? British Journal of Management, 29, 796-816. https://doi.org/10.1111/1467-8551.12275

Binnewies, C., \& Gromer, M. (2012). Creativity and Innovation at Work: The Role of Work Characteristics and Personal Initiative. Psicothema, 24, 100-105.

Borasi, R., \& Finnigan, K. (2010). Entrepreneurial Attitudes and Behaviors that Can Help Prepare Successful Change-Agents in Education. New Educator, 6, 1-29. https://doi.org/10.1080/1547688X.2010.10399586

Bourgonjon, J., De Grove, F., De Smet, C., Van Looy, J., Soetaert, R., \& Valcke, M. (2013). Acceptance of Game-Based Learning by Secondary School Teachers. Computers and Education, 67, 21-35. https://doi.org/10.1016/j.compedu.2013.02.010

Catio, M. (2019). Analyzing the Competency of Principals Using the Framework of the Wales National Standard for Head Teacher in Boosting Teacher's Innovative Behavior. International Journal of Managerial Studies and Research, 7, 1-6. https://doi.org/10.20431/2349-0349.0702001

Celik, K. (2013). The Relationship between Individual Innovativeness and Self-efficacy Levels of Student Teachers. International Journal of Scientific Research in Education, 6, 56-67.

Chang, C. P., Chuang, H. W., \& Bennington, L. (2011). Organizational Climate for Innovation and Creative Teaching in Urban and Rural Schools. Quality and Quantity, 45, 935-951. https://doi.org/10.1007/s11135-010-9405-X

Choi, S. B., Kim, K., Ullah, S. M. E., \& Kang, S. W. (2016). How Transformational Leadership Facilitates Innovative Behavior of Korean Workers: Examining Mediating and Moderating Processes. Personnel Review, 45, 459-479.

https://doi.org/10.1108/PR-03-2014-0058

Chou, C. M., Shen, C. H., Hsiao, H. C., \& Shen, T. C. (2019). Factors Influencing Teachers' Innovative Teaching Behaviour with Information and Communication Technology 
(ICT): The Mediator Role of Organizational Innovation Climate. Educational Psychology, 39, 65-85. https://doi.org/10.1080/01443410.2018.1520201

Çoklar, A. N., \& Özbek, A. (2017). Analyzing of Relationship between Teachers' Individual Innovativeness Levels and Their Tpack Self-Efficacies. Journal of Human Sciences, 14, 427-440. https://doi.org/10.14687/jhs.v14i1.4413

De Vries, H., Bekkers, V., \& Tummers, L. (2016). Innovation in the Public Sector: A Systematic Review and Future Research Agenda. Public Administration, 94, 146-166. https://doi.org/10.1111/padm.12209

Devloo, T., Anseel, F., De Beuckelaer, A., \& Salanova, M. (2015). Keep the Fire Burning: Reciprocal Gains of Basic Need Satisfaction, Intrinsic Motivation and Innovative Work Behaviour. European Journal of Work and Organizational Psychology, 24, 491-504. https://doi.org/10.1080/1359432X.2014.931326

Dinh, J. E., Lord, R. G., Gardner, W. L., Meuser, J. D., Liden, R. C., \& Hu, J. (2014). Leadership Theory and Research in the New Millennium: Current Theoretical Trends and Changing Perspectives. The Leadership Quarterly, 25, 36-62.

https://doi.org/10.1016/j.leaqua.2013.11.005

Doç, Y., \& Yapıcı, İ. Ü. (2016). Investigation of the Individual Innovativeness Levels of the Pre-Service Biology Teachers. Journal of Research in Education and Teaching, 5, $35-44$.

Donnelly, D., McGarr, O., \& O’Reilly, J. (2011). A Framework for Teachers' Integration of ICT into Their Classroom Practice. Computers and Education, 57, 1469-1483. https://doi.org/10.1016/j.compedu.2011.02.014

Gkorezis, P. (2016). Principal Empowering Leadership and Teacher Innovative Behavior: A Moderated Mediation Model. International Journal of Educational Management, 30, 1030-1044. https://doi.org/10.1108/IJEM-08-2015-0113

Hsiao, H., Chen, S., Chang, J. C., \& Tu, Y. L. (2011). The Influence of Teachers' Self-efficacy on Innovative Work Behavior. In 2011 International Conference on Social Science and Humanity (Vol. 5, pp. 233-237).

Huang, X., Lee, J. C. K., \& Dong, X. (2019). Mapping the Factors Influencing Creative Teaching in Mainland China: An Exploratory Study. Thinking Skills and Creativity, 31, 79-90. https://doi.org/10.1016/j.tsc.2018.11.002

Iqra, A., Rozeyta, O., \& Siti Aisyha, P. (2016). A Literature Review on Personality, Creativity and Innovative Behavior. International Review of Management and Marketing, 6, 177-182.

Izzati, U. A. (2018). The Relationships between Vocational High School Teachers' Organizational Climate and Innovative Behavior. Advances in Social Science, Education and Humanities Research, 173, 343-345. https://doi.org/10.2991/icei-17.2018.91

Javed Iqbal, G. A., Waheed, A., \& Naveed Riaz, M. (2012). Relationship between Transformational Leadership Style and Innovative Work Behavior in Educational Institutions. Journal of Behavioural Sciences, 22, 18-32.

Karabulut-Ilgu, A., Jaramillo Cherrez, N., \& Jahren, C. T. (2018). A Systematic Review of Research on the Flipped Learning Method in Engineering Education. British Journal of Educational Technology, 49, 398-411. https://doi.org/10.1111/bjet.12548

Khan, A., Fleva, E., \& Qazi, T. (2015). Role of Self-Esteem and General Self-Efficacy in Teachers' Efficacy in Primary Schools. Psychology, 6, 117-125.

https://doi.org/10.4236/psych.2015.61010

Klaeijsen, A., Vermeulen, M., \& Martens, R. (2018). Teachers' Innovative Behaviour: The Importance of Basic Psychological Need Satisfaction, Intrinsic Motivation, and Occu- 
pational Self-Efficacy. Scandinavian Journal of Educational Research, 62, 769-782. https://doi.org/10.1080/00313831.2017.1306803

Kundu, A., \& Roy, D. D. (2016). School Climate Perception and Innovative Work Behaviour of School Teachers. International Journal of Education and Psychological Research, 5, 129-133. https://doi.org/10.21863/johb/2016.5.1.024

Lecat, A., Beausaert, S., \& Raemdonck, I. (2018). On the Relation Between Teachers' (In)formal Learning and Innovative Working Behavior: The Mediating Role of Employability. Vocations and Learning, 11, 529-555.

https://doi.org/10.1007/s12186-018-9199-x

Leong, C. T., \& Rasli, A. (2014). The Relationship between Innovative Work Behavior on Work Role Performance: An Empirical Study The Relationship between Innovative Work Behavior on Work Role Performance: An Empirical Study. Procedia-Social and Behavioral Sciences, 129, 592-600. https://doi.org/10.1016/j.sbspro.2014.03.717

Li, M., Liu, Y., Liu, L., \& Wang, Z. (2017). Proactive Personality and Innovative Work Behavior: the Mediating Effects of Affective States and Creative Self-Efficacy in Teachers. Current Psychology, 36, 697-706. https://doi.org/10.1007/s12144-016-9457-8

Loogma, K., Kruusvall, J., \& Ümarik, M. (2012). E-Learning as Innovation: Exploring Innovativeness of the VET Teachers' Community in Estonia. Computers and Education, 58, 808-817. https://doi.org/10.1016/j.compedu.2011.10.005

Masood, M., \& Afsar, B. (2017). Transformational Leadership and Innovative Work Behavior among Nursing Staff. Nursing Inquiry, 24, e12188.

https://doi.org/10.1111/nin.12188

McDougall, J. (2010). A Crisis of Professional Identity: How Primary Teachers Are Coming to Terms with Changing Views of Literacy. Teaching and Teacher Education, 26, 679-687. https://doi.org/10.1016/j.tate.2009.10.003

Melor, M. Y. (2018). Innovation in Education and Language Learning in 21st Century. Journal of Sustainable Development Education and Research, 2, 33-34.

Messmann, G., \& Mulder, R. H. (2011). Innovative Work Behaviour in Vocational Colleges: Understanding How and Why Innovations Are Developed. Vocations and Learning, 4, 63-84. https://doi.org/10.1007/s12186-010-9049-y

Messmann, G., Stoffers, J., van der Heijden, B., \& Mulder, R. H. (2017). Joint Effects of Job Demands and Job Resources on Vocational Teachers' Innovative Work Behaviour. Personnel Review, 46, 1948-1961. https://doi.org/10.1108/PR-03-2016-0053

Moghimi, S., \& Muenjohn, N. (2014). The Conceptual Link between Leadership and Innovation: The Role of Organizational Climate and Personal Initiative. In The Asian Conference on Business \& Public Policy 2014 (pp. 1-18).

Moher, D., Liberati, A., Tetzlaff, J., \& Altman, D. G. (2009). Preferred Reporting Items for Systematic Reviews and Meta-Analyses: The PRISMA Statement. Journal of Clinical Epidemiology, 62, 1006-1012. https://doi.org/10.1016/j.jclinepi.2009.06.005

Mokhber, M., Khairuzzaman, W., \& Vakilbashi, A. (2018). Leadership and Innovation: The Moderator Role of Organization Support for Innovative Behaviors. Journal of Management and Organization, 24, 108-128. https://doi.org/10.1017/jmo.2017.26

Nakata, Y. (2011). Teachers' Readiness for Promoting Learner Autonomy: A Study of Japanese EFL High School Teachers. Teaching and Teacher Education, 27, 900-910. https://doi.org/10.1016/j.tate.2011.03.001

Nemeržitski, S., Loogma, K., Heinla, E., \& Eisenschmidt, E. (2013). Constructing Model of Teachers' Innovative Behaviour in School Environment. Teachers and Teaching: Theory and Practice, 19, 398-418. https://doi.org/10.1080/13540602.2013.770230 
Ng, W., Nicholas, H., \& Williams, A. (2010). School Experience Influences on Pre-Service Teachers' Evolving Beliefs about Effective Teaching. Teaching and Teacher Education, 101, 50-61. https://doi.org/10.1016/j.tate.2009.03.010

Noh, N. M., Hamzah, M., \& Abdullah, N. (2016). The Influence of Demographic Factor on Personal Innovativeness towards Technology Acceptance. Malaysian Online Journal of Educational Technology, 4, 68-75.

Norita, I. (2012). Kepimpinan Instruksional Pengetua, Kerenah Birokrasi dan Efikasi Kendiri Guru Di Daerah Pasir Puteh, Kelantan. Kuala Lumpur, Malaysia: Universiti Malaya.

Opfer, V. D., Pedder, D. G., \& Lavicza, Z. (2011). The Role of Teachers' Orientation to Learning in Professional Development and Change: A National Study of Teachers in England. Teaching and Teacher Education, 27, 443-453.

https://doi.org/10.1016/j.tate.2010.09.014

Petticrew, M., \& Roberts, H. (2006). Systematic Reviews in the Social Sciences: A Practical Guide. Oxford: Blackwell. https://doi.org/10.1002/9780470754887

Pieterse, A. N., van Knippenberg, D., Schippers, M., \& Stam, D. (2010). Transformational and Transactional Leadership and Innovative Behavior: The Moderating Role of Psychological Empowerment. Journal of Organizational Behavior, 31, 609-623. https://doi.org/10.1002/job.650

Ramli, N., Abdul, N., \& Halim, N. A. (2015). Innovative Behavior in Educational Institutions: The Role of Transformational Leadership and Teamwork Attitude. Journal of Management Sciences, 1, 39-62.

Runhaar, P., Bednall, T., Sanders, K., \& Yang, H. (2016). Promoting VET Teachers' Innovative Behaviour: Exploring the Roles of Task Interdependence, Learning Goal Orientation and Occupational Self-Efficacy. Journal of Vocational Education \& Training, 68, 436-452. https://doi.org/10.1080/13636820.2016.1231215

Sağnak, M., Kuruöz, M., Polat, B., \& Soylu, A. (2015). Transformational Leadership and Innovative Climate: An Examination of the Mediating Effect of Psychological Empowerment (Dönüşümcü liderlik ve yenilikçi iklim: Psikolojik güçlendirmenin aracılık etkisinin incelenmesi). Egitim Arastirmalari-Eurasian Journal of Educational Research, 15, 149-162. https://doi.org/10.14689/ejer.2015.60.9

Schunk, D. H., \& DiBenedetto, M. K. (2016). Self-Efficacy theory in Education. In Handbook of Motivation at School: Second Edition (pp. 34-52).

Sellars, M. (2012). Teachers and Change: The Role of Reflective Practice. Procedia-Social and Behavioral Sciences, 55, 461-469. https://doi.org/10.1016/j.sbspro.2012.09.525

Shahab, H., \& Imran, R. (2018). Cultivating University Teachers' Innovative Work Behavior: The Case of Pakistan. Business \& Economic Review, 10, 159-178.

https://doi.org/10.22547/BER/10.1.7

Shamsudin, A., \& Rosadah, A. M. (2018). Efikasi Kendiri Guru Sekolah Dalam Hospital di Malaysia. Journal of Social Sciences and Humanities, 13, 20-28.

Suharyati, H. (2017). Interaction of Relationship between Job Motivation with Teacher Innovativeness in Improving Education. Journal of Education, Teaching and Learning, 2, 228-232. https://doi.org/10.26737/jetl.v2i2.291

Thurlings, M., Evers, A. T., \& Vermeulen, M. (2015). Toward a Model of Explaining Teachers' Innovative Behavior: A Literature Review. Review of Educational Research, 85, 430-471. https://doi.org/10.3102/0034654314557949

Tims, M., Bakker, A. B., \& Derks, D. (2014). Daily Job Crafting and the Self-Efficacy Performance Relationship. Journal of Managerial Psychology, 29, 490-507. 
https://doi.org/10.1108/JMP-05-2012-0148

Vogel, R., \& Masal, D. (2015). Public Leadership: A Review of the Literature and Framework for Future Research. Public Management Review, 17, 1165-1189. https://doi.org/10.1080/14719037.2014.895031

Wang, Y. X., Yang, Y. J., Wang, Y., Su, D., Li, S. W., Zhang, T., \& Li, H. P. (2019). The Mediating Role of Inclusive Leadership: Work Engagement and Innovative behaviour among Chinese Head Nurses. Journal of Nursing Management, 27, 688-696. https://doi.org/10.1111/jonm.12754

Yilmaz, O., \& Bayraktar, D. M. (2014). Teachers' Attitudes towards the Use of Educational Technologies and Their Individual Innovativeness Categories. Procedia-Social and Behavioral Sciences, 116, 3458-3461. https://doi.org/10.1016/j.sbspro.2014.01.783

Yorulmaz, A., Çokçalişkan, H., \& Önal, H. (2016). Determination of Classroom Pre-Service Teachers' State of Personal Innovativeness. Journal of Education and Training Studies, 5, 28-34. https://doi.org/10.11114/jets.v5i1.1947

Zennouche, M., Zhang, J., \& Wang, B. W. (2014). Factors Influencing Innovation at Individual, Group and Organisational Levels: A Content Analysis. International Journal of Information Systems and Change Management, 7, 23-42.

https://doi.org/10.1504/IJISCM.2014.065052 